\title{
РАЗДЕЛ II.МЕНЕДЖМЕНТ
}

\section{Джабаева П.Д., Магомедова Д.М. \\ Влияние стиля коммуникаций руководителя на мотивацию персонала организации}

Дагестанский Государственный университет

(Россия, Махачкала)

doi:10.18411/sciencepublic-08-12-2019-07

idsp: sciencepublic-08-12-2019-07

\section{Аннотация}

Стиль коммуникации руководителя во многом определяет успех организации. В данной статье будут рассмотрены качественные характеристики лидера, и будет обозначено влияние, которое они оказывают на мотивацию и производительность каждого отдельного сотрудника.

Ключевые слова: лидерство, управление, руководитель, коммуникации, мотивация, влияние на людей.

Руководитель любой организации должен быть лидером, ведь именно лидер помогает продвигаться вперед всему персоналу на пути к успеху. Никакой успех в управлении не компенсирует провала в лидерстве [1, с.119].

Самой важной ролью лидера является формирование четкого, достижимого и мотивирующего видения.

Это видение и его поддержка в душе у всего персонала обеспечивается уникальными человеческими дарами - воображением и совестью.

Воображение позволяет нам увидеть еще не созданные миры заключенных в нас потенциальных возможностей. Совесть обеспечивает наше понимание универсальных законов и принципов, наших собственных удивительных талантов и нашего участия в общем деле, а также ее персональных правил, благодаря которым мы можем развивать все это максимально эффективно[2, с. 120].

Для того, чтобы можно было определить, что руководителю организации в первую очередь нужно заниматься лидерством, а не управлением, рассмотрим пример, который приводится в зарубежной литературе.

Руководитель нефтяной компании столкнулся с проблемой мотивации персонала. Фокус деятельности бизнесмена был направлен в первую очередь на осуществление управления.

Прекратив решение задач, которые дают краткосрочное ощущение позитивной отдачи, он в первое время не получал удовлетворения от выбора направления развития, способов коммуникации как с работниками, так и с внешней средой, от решения сложных проблем, которые дают долгосрочный положительный результат. В первую очередь было осуществлено делегирование полномочий относительно управления подчиненным, тем самым повысив уровень доверия между ними. Это было правильным решением, но его сотрудники прошли через мучительный отказ от того, к чему успели привыкнуть. Можно быть абсолютно уверенным в том, что после изменения направления деятельности руководства организации, компания преобразилась.

Лингвистические исследования показывают прямую связь между статусом человека и его словарным запасом. Чем выше положение человека, тем лучше он формулирует свои мысли и строит предложения. Исследования языка телодвижений показывают взаимосвязь между тем, как человек формулирует свои мысли, и его 
жестами. Чем выше социально-экономическое положение человека, тем меньше он жестикулирует и тем меньше телодвижений совершает [3, с.379].

Делегирование полномочий, как было упомянуто, влечет положительные последствия. Стоит сделать акцент также на других приемах эффективного процесса коммуникаций.

Во-первых, последовательность высшего руководства в продвижении своих идей с увеличения приверженности работников к общей цели. Большое значение имеет возможность менеджера исключить вероятности наступления желательных событий и превратить их в факты.

Во-вторых, умение руководителя контролировать свои эмоции, быть уверенным в себе в процессе общения с персоналом. Для того, чтобы сотрудники верили в то, что они делают, высшее руководство в продвижении идей должны быть постоянны.

В-третьих, использование эффективных ментальных приемов и своей харизмы помогает исключить вероятности наступления неблагоприятных последствий для руководителя.

В-четвертых, превосходное ораторское искусство является одной из самых значимых характеристик менеджера. Умение общаться с публикой влияет на впечатление окружающих о его умении управлять предприятием и наоборот.

В-пятых, способность принимать точку зрения оппонента, не применять жесткую, неконструктивную критику в его адрес способствует дальнейшему развитию хозяйствующего субъекта.

Можно сделать вывод, что успешный лидер должен обладать целым рядом хорошо отработанных методик и приемов управления, также ему необходимо уметь чувствовать ситуацию и понимать, как оказать влияние на отдельную личность и на группу людей.

$$
* * *
$$

1. Семь навыков высокоэффективных людей: Мощные инструменты развития личности / Стивен Р. Кови; Пер.с англ.- 13-е изд., доп. - М.: Альпина Паблишер, 2019.- 396 с.

2. Новый язык телодвижений. Расширенная версия. - М.: Эксмо, 2011. - 416 с., ил.

\section{Ламихов Ю.Б. \\ Лояльность персонала как условие благоприятного социально-психологического климата в коллективе}

Саратовский национальный исследовательский государственный университет имени Н. Г. Чернылшевского (Россия, Саратов)

doi:10.18411/sciencepublic-08-12-2019-08

idsp: sciencepublic-08-12-2019-08

\section{Аннотация}

В статье представлены результаты социологического исследования уровня лояльности персонала на предприятиях Саратовской области. Лояльность персонала считается одной из важнейших составляющих, способной обеспечить финансовый успех предприятия, что обусловливает актуальность исследования. Исследование позволило получить объективные представления о том, насколько данные компании готовы к активному развитию и росту в тот или иной момент своего существования. Анализ результатов помогает работодателю быстро отреагировать по вопросам формирования эффективной системы трудовой мотивации.

Ключевые слова: лояльность персонала, социально-психологический климат в коллективе, трудовая мотивация. 